\title{
Generalizing the Definition of "Physical Culture"
}

\author{
Vasil Opanasovych Sutula* \\ Professor, Doctor of Education, Kharkiv State Academy of Physical Culture, Europe
}

Submission: March 08, 2018; Published: March 20, 2018

*Corresponding author: Vasil Opanasovych Sutula, Professor, Doctor of Education, Kharkiv State Academy of Physical Culture, Europe, Tel: 067-70-50-491; Email: vsutula@rambler.ru

\begin{abstract}
Peculiarities of using the term "physical culture" in modern European, Anglo-American and Soviet scientific practice. It is shown that at present there is no scientific justification concept for the name which is used. Established is that physical training is a historically caused by the activities of people using exercise, and the results of such activities. Disclosed sequence of the formation of physical culture theory.g.
\end{abstract}

Keywords: Physical Education; Theory; Activity; Generalized Definition

\section{Introduction}

\section{Problem, Analysis of Recent Research and Publications}

Analysis of the use of scientific and methodological literature of the term "physical culture" indicates the presence of severe tensions. On the one hand, the term is widely used in education and science, the law, in language practice [1-6], on the other, there is no generally accepted definition for the name of which it is used [7-11]. It is clear that solving the existing contradictions that is the wording of generalizing of the concept of physical training is a key prerequisite for the development of the theory.

\section{The purpose of the Study}

Is drawing attention to the scientific and educational community to the problems of development of the theory of physical culture.

\section{Result and Discussion}

Basic approaches to defining the essence of the concept of "physical culture" are used in modern Anglo-American and national practice is presented in Table 1 . Of these it shows that all formulations focus on two components of physical culture active and resulting. Thus, the activity-constituent states that physical education occurs and is caused by human activity. This item is specified in the definition proposed by research center experts «Center for Physical Culture and Sports» (USA) [12], follows "performed by them for centuries". So, finally the physical culture, considering this specification, it is advisable to use the phrase "historically caused by human activities."
From Table 1 presented is the material also shows that the resulting component in terms of displays presented individually significant (!) the result of human activity in the sphere of physical culture (which is characteristic of all definitions), namely, improving health, improving physique, improve external appearance, harmonious (maximum) physical development, improve the overall physical fitness (strength, endurance, flexibility, quickness), the formation of physical readiness of human life, healthy lifestyles, improve athletic performance and increase knowledge about the sport, the aging control. Specified list could be expanded to include more and socially significant results (!) physical activity of people (not existed in current terms). For instance, created as a result of such development a system specific for this type of cultural values, ideals, norms and patterns of behavior, social phenomena and processes that result from such activity and around the infrastructure (stadiums, gyms, etc.) system of training methods using exercise special literature and more. The need for adjustments made ("individually significant" and "socially significant" results of human activities in the field of physical culture) is due to the fact that human is both subject and object of cultural-historical process. That means that such activity has two dimensions. On the one hand, it must be considered from the perspective of today, on the other, it should be analyzed in the context of cultural-historical process [2]. Taken into account the diversity of activity of the people in the field of physical culture and above arguments it would be appropriate the resulting component in general terms to characterize as "results of that activity" without their list obviously cannot cover all possible outcomes of such activities. 
Table 1: The essence of the concept of "physical culture", which is used in modern Anglo-American and domestic practice.

\begin{tabular}{|c|c|c|}
\hline № $\mathbf{p} / \mathbf{p}$ & Anglo-American and European Practice & World Practice \\
\hline 1 & $\begin{array}{l}\text { Physical culture is a term used to describe } \\
\text { the various activities people have employed } \\
\text { over the centuries to strengthen their bodies, } \\
\text { enhance their physiques, increase their } \\
\text { endurance, enhance their health, fight against } \\
\text { aging, and become better athletes. HJ Lutcher } \\
\text { Stark Center for Physical Culture and Sports } \\
\text { [13] }\end{array}$ & $\begin{array}{l}\text { Physical culture - the kind of human culture } \\
\text { and society. This activity and its results are in } \\
\text { formation of physical readiness for life. On the } \\
\text { one hand, this specific process, on the other } \\
\text { - the result of human activity and the means } \\
\text { and method of human physical perfection. } \\
\text { T Krutsevych, G Bezverkhnii [3] }\end{array}$ \\
\hline 2 & $\begin{array}{l}\text { Physical culture, philosophy, regimen, } \\
\text { or lifestyle seeking maximum physical } \\
\text { development through such means as weight } \\
\text { (resistance) training, diet, aerobic activity, } \\
\text { athletic competition, and mental discipline. } \\
\text { Specific benefits include improvement in } \\
\text { health, appearance, strength, endurance, } \\
\text { flexibility, speed, and general fitness as well as } \\
\text { greater proficiency in sport-related activities. } \\
\text { Encyclopædia Britannica }\end{array}$ & $\begin{array}{l}\text { Physical culture - the kind of human culture } \\
\text { and society. This activity and its results are in } \\
\text { formation of physical readiness for life. On the } \\
\text { one hand, this specific process, on the other } \\
\text { - the result of human activity and the means } \\
\text { and method of human physical perfection. } \\
\text { T Krutsevych, G Bezverkhnii [3] }\end{array}$ \\
\hline
\end{tabular}

Analysis of existing definitions of physical culture also shows that they do not reflect the particular conditions of the people in the field of physical culture. That is no information on the specific tools used in the culture-people activities, thus did not reflected how special that is inherent to this type of culture that it generates and allocates this kind of culture among others. Note that this feature is universal; it manifests itself in all definitions of physical culture, which draws the attention of Professor John D Fair [10], as well as the definitions used by domestic scientists. Obviously, the primary means by which a variety of human needs are realized in the field of physical culture are physical exercises, and those who do not have it direct utilitarian value (instant benefits). In this feature exercise drew attention in 1924 H Dyuperron who noted that "... within this utilitarism ties in difference of movements in general bron exercises of physical culture" $[13,14]$. So exercises are the hallmark of this type of culture, a kind of pivot around which combines motility of man and his spiritual development in the specialized activities. They are that fundamental "bricks", which are the basis of the unity of the various forms of social manifestation of physical culture. Considering the above definition of a generalized physical training it should be made needed to specify components, namely, the phrase "use of physical exercise".

The above analysis allows us to formulate generalized definition of Physical culture as follows. Physical culture is a historically caused by the activities of people with using exercises, and the results of such activities. The wording of this definition is a key prerequisite for the development of the theory of physical culture because it focuses on its main specific characteristics and makes it possible with one voice to determine the nature of the various forms of social manifestation of physical culture (physical education, sport and physical recreation, physical rehabilitation and adaptive physical culture) and indicates the sequence process of this theory to develop.

\section{Conclusion}

a) Analysis of the features use of European and AngloAmerican scientific practice of the term "physical culture" indicates the presence of severe contradictions. On the one hand, the term is widely used in education and science, law, language in practice and on the other, there is no scientific justification concept for the name of which it is introduced. Indicated contradiction as the analysis cannot be resolved within the existing theoretical concepts (theory and methodology of physical education, sports theory, etc.). Because it is both a cause and consequence of the theory of physical education which is not formed so far.

b) The results of the analysis indicate that physical culture is a historically caused by the activities of people using exercises, and the results of such activities.

c) Based on the summary determination of physical culture, namely the notion that physical culture is formed as a result of human activities to meet the diverse needs of exercises, it can be concluded that the first step towards the development of the theory is self-selection mechanism of such activities. Specified approach involves finding out the nature and structure of human needs to use exercises principles of their formation, their relationships and patterns of change in the development of physical culture.

d) Based on the determination of synthesis, namely the statement of the fact that physical culture is the result of historically due to human activities, the second step in the development of the theory is to elucidate the mechanism of historical self-development of social phenomena and processes, which are based on human activities to use of exercises. It needs to consider the fact that the emergence of modern forms of social manifestation of physical culture 
(physical education, sport, physical recreation, physical rehabilitation and adaptive physical education) are the result of historical evolution and their development is inextricably linked to the evolution of socio-economic, political and cultural relations, which are formed at a certain stage of historical development of human society.

\section{References}

1. Law of Ukraine "On Physical Culture and Sports".

2. Sutula VO (2002) Fundamentals fyzkulturolohyy. Bar, Kharkov, Europe, p. 87.

3. Sutula VO (2013) Theory of Physical Culture: Myth or nauchny reality? In: VO Sutula, GV Vlasov (Eds.), Theory and Practice of Physical Culture, Russia, 5: 10-14

4. John Balik «Cultivating Physical Culture».

5. John Sifferman «Physical Culture: it's more than just bodybuilding muscles, and old-time strongmen training culture».

6. Morris A (2000) Modern Chinese Sport and Physical Culture. Society for Comparative Study of Society and History 879-906.
7. Krutsevych T (2010) Recreation in physical culture of different groups, Teach guidance's. In: T Krutsevych, GV Bezverkhnii. K: Olympic Books, Russia, pp. 248.

8. Kuramshyn YF (2010) Theory and Methods of Physical Culture. Soviet sport, Russia, pp. 320.

9. Cleopahas F (2009) Physical education and physical culture in the coloured community of the western cape pp. 302 .

10. John D Fair «Physical culture».

11. Kosiewicz Jerzy (2010) Social and Biological Context of Physical Culture and Sport. Physical Culture and Sport Studies and Research 50(50): 5-31.

12. HJ Lutcher Stark Center for Physical Culture and Sports.

13. Dyuperon GA (1924) Brief history fyzycheskyh course exercises. Leningrad edition fyzycheskoho school education Komsostava KA and F, p. 71.

14. Encyclopædia Britannica.

\section{Your next submission with Juniper Publishers will reach you the below assets}

- Quality Editorial service

- Swift Peer Review

- Reprints availability

- E-prints Service

- Manuscript Podcast for convenient understanding

- Global attainment for your research

- Manuscript accessibility in different formats

( Pdf, E-pub, Full Text, Audio)

- Unceasing customer service

Track the below URL for one-step submission https://juniperpublishers.com/online-submission.php 